\title{
PENGARUH PENDIDIKAN KEWIRAUSAHAAN TERHADAP MINAT BERWIRAUSAHA MAHASISWA UNIVERSITAS SAMAWA SUMBAWA BESAR
}

\author{
Ana Merdekawaty ${ }^{1)}$, Ismawati ${ }^{2}$ \\ 1) Dosen Prodi Pendidikan Ekonomi, FKIP Universitas Samawa \\ Email: ana.merdekawati90@gmail.com \\ wisma1181@yahoo.co.id
}

\begin{abstract}
Abstrak
Penelitian ini bertujuan untuk mengetahui pengaruh pendidikan kewirausahaan terhadap minat berwirausaha mahasiswa Universitas Samawa Sumbawa Besar. Penelitian ini menggunakan metode kuantitatif. Populasi berjumlah 320 mahasiswa dengan Sampel 120 mahasiswa. Teknik pengumpulan data menggunakan kuisioner dan dokumentasi. Instrumen penelitian menggunakan angket sedangkan untuk analisis data menggunakan regresi linier berganda. Berdasarkan hasil analisis data, diperoleh kesimpulan bahwa pendidikan kewirausahaan berpengaruh signifikan terhadap minat berwirausaha mahasiswa Universitas Samawa Sumbawa Besar. Berdasarkan simpulan tersebut, maka disarankan bagi dosen pengampu mata kuliah kewirausahaan, untuk merancang kurikulum yang mengarah pada pembentukan karakter/sikap wirausaha mahasiswa. Sehingga output setelah mengikuti mata kuliah kewirausahaan, mahasiswa tidak hanya memperoleh nilai hasil belajar akan tetapi mampu memotivasi dirinya untuk berwirausaha.
\end{abstract}

Kata Kunci: Pendidikan Kewirausahaan, Minat Berwirausaha, Mahasiswa

\section{PENDAHULUAN}

Fenomena rendahnya minat dan motivasi pemuda Indonesia untuk berwirausaha dewasa ini menjadi pemikiran serius berbagai pihak, baik pemerintah, dunia pendidikan, dunia industri, maupun masyarakat. Staf Ahli menteri koperasi dan UKM bidang penerapan nilai dasar Koperasi, Drs. Sutarno mengatakan minat mahasiswa untuk berwirausaha masih rendah, dari 4,8 juta mahasiswa, hanya 7,4 persen yang meminati wirausaha. Rendahnya minat wirausaha tersebut juga diketahui dari data di Kemendikbud yang mencatat bahwa 60,87 persen lulusan SLTA dan 83,18 persen lulusan perguruan tinggi lebih berminat menjadi pekerja atau karyawan kantor. Direktorat Jenderal Pendidikan Tinggi (2010), menyebutkan bahwa sebagian besar lulusan perguruan tinggi cenderung memilih sebagai pencari kerja daripada pencipta lapangan pekerjaan.

Realitas bahwa sangat tingginya angka pengangguran terdidik yang semakin memprihatinkan dan sangat terbatasnya lapangan pekerjaan yang ada, nampaknya masih belum mampu menyadarkan atau menggugah mahasiswa untuk mengubah orientasinya. Tidak bisa dipungkiri bahwa sebagian besar lulusan Perguruan Tinggi masih berorientasi sebagai pencari kerja (job seeker) daripada sebagai pencipta kerja (job creator). Hal ini terjadi karena sistem pembelajaran di berbagai perguruan tinggi masih terfokus pada bagaimana menyiapkan para mahasiswa yang cepat lulus dan mendapatkan pekerjaan, bukannya lulusan yang siap menciptakan pekerjaan. Indikasinya adalah banyak lulusan yang walaupun berpengetahuan tinggi tetapi kurang mampu mensejahterakan diri dan lingkungannya. Oleh karenanya pendidikan tinggi di Indonesia perlu lebih menyiapkan lulusannya menjadi sarjana yang mampu hidup mandiri, berkreasi, memanfaatkan sains dan teknologi serta seni yang telah dipelajarinya.

Masalah rendahnya minat wirausaha lulusan merupakan sebuah tugas khusus bagi perguruan tinggi untuk ikut berperan serta dalam mencetak lulusan yang lebih berkualitas, menciptakan pembelajaran yang mampu membentuk lulusan yang memiliki sikap mental 
wirausaha, sehingga setelah lulus akan banyak mahasiswa yang berminat terjun dalam dunia wirausaha.

Berbagai upaya dilakukan untuk menumbuhkan jiwa kewirausahaan terutama merubah mindset para pemuda yang selama ini hanya berminat sebagai pencari kerja apabila kelak menyelesaikan sekolah atau kuliah mereka. Hal ini merupakan tantangan bagi pihak sekolah dan perguruan tinggi sebagai lembaga penghasil lulusan.

Jiwa dan semangat kewirausahaan memainkan peranan yang sangat penting dalam dunia bisnis dan ekonomi dewasa ini. Apalagi, belakangan ini elemen pemerintahan dan intelektual sangat menekankan pentingnya jiwa kewirausahaan di kalangan mahasiswa. Semangat kewirausahaan dianggap perlu dibangun sejak dini sebagai fondasi di masa depan agar lapangan pekerjaan semakin terbuka lebar dengan iklim bisnis yang penuh dengan inovasi. Mahasiswa sebagai salah satu kaum intelek dan tulang punggung reformasi di masa depan, merupakan kalangan yang dipandang perlu membekali diri dengan semangat dan jiwa berwirausaha. Mahasiswa ditantang untuk menciptakan lapangan pekerjaan sendiri dengan cara-cara dan ide yang inovatif.

Semua perguruan tinggi di Indonesia telah memasukkan mata kuliah kewirausahaan ke dalam kurikulum mereka sebagai salah satu mata kuliah pokok yang wajib ditempuh oleh semua mahasiswa. Pendidikan kewirausahaan tidak hanya memberikan landasan teoritis mengenai konsep kewirausahaan tetapi membentuk sikap, perilaku, dan pola pikir (mindset) seorang wirausahawan (entrepreneur). Hal ini merupakan investasi modal manusia untuk mempersiapkan para mahasiswa dalam memulai bisnis baru melalui integrasi pengalaman, keterampilan, dan pengetahuan penting untuk mengembangkan dan memperluas sebuah bisnis. Pendidikan kewirausahaan juga dapat meningkatkan minat para mahasiswa untuk memilih kewirausahaan sebagai salah satu pilihan karir selain pilihan karir menjadi pegawai swasta, PNS, atau pegawai BUMN.

Universitas Samawa sebagai salah satu perguruan tinggi yang ada di Kabupaten Sumbawa telah cukup lama membekali mahasiswanya untuk menjadi wirausaha melalui mata kuliah kewirausahaan. Sejumlah aktivitas telah dilakukan pada mata kulaiah ini, yaitu tentang teori-teori kewirausahaan, praktik kewirausahaan dengan membuat berbagai jenis produk serta berperan aktif dalam program kreativitas mahasiswa (PKM). Dengan demikian mahasiswa dapat memiliki mental berwirauaha dan mendorong untuk menjadi wirausaha yang sesungguhnya setelah mereka diwisuda. Namun, hal tersebut perlu dikaji lebih lanjut apakah dengan adanya pendidikan kewirausahaan dapat melahirkan minat berwirausaha bagi mahasiswa. Oleh karena, itu perlu adanya penelitian untuk mengetahui pengaruh pendidikan kewirausahaan terhadap minat berwirausaha mahasiswa mengingat pentingnya kewirausahaan bagi kesejahteraan ekonomi dan sosial.

\section{TINJAUAN PUSTAKA}

\section{Minat}

Minat atau keinginan erat hubungannya dengan perhatian yang dimiliki. Karena perhatian mengarahkan timbulnya keinginan pada seseorang. Menurut Ahmadi (2009:98), minat adalah sikap jiwa orang seorang, termasuk emosi, yang tertuju pada sesuatu, dan dalam hubungan itu unsur perasaan yang terkuat. Sedangkan menurut slameto (2009), minat adalah kecenderungan jiwa untuk tetap memperhatikan dan mengenang beberapa aktivitas atau kegiatan. Seseorang yang berminat suatu aktivitas dan memperhatikan itu secara konsisten dengan rasa senang.

Rast, Harmin dan Simon (dalam Mulyati, 2005:46), menyatakan bahwa dalam minat itu ada hal-hal pokok diantaranya: 1) adanya perasaan senang dalam diri yang memberikan perhatian pada objek tertentu, 2) adanya ketertarikan pada objek, 3) adanya aktivitas terhadap objek, 4) adanya kecenderungan berusaha lebih aktif, 5) kecenderungan mengarah dan mempengaruhi perilaku individu. 


\section{Wirausaha}

Menurut Mas'ud Machfoed (dalam Lestari, 2012), wirausaha adalah seorang inovator yang mampu mengubah kesempatan menjadi sebuah ide yang bisa di jual, dapat memberikan nilai tambah melalui upaya, waktu, biaya serta kecakapan dengan tujuan mendapatkan keuntungan. Menurut Buchari Alma (2010: 21), wirausaha adalah orang yang melihat adanya peluang kemudian menciptakan sebuah organisasi untuk memanfaatkan peluang tesebut.

Minat berwirausaha dapat dilihat dari dua indikator utama, yaitu : (1) seberapa kuat upaya seseorang untuk berani mencoba melakukan aktivitas kewirausahaan: (2) seberapa banyak upaya yang direncanakan seseorang untuk malakukan aktivitas kewirausahaan.

\section{Minat Berwirausaha}

Menurut Fuadi (2009:93), minat wirausaha adalah keinginan, ketertarikan, serta kesediaan untuk bekerja keras atau berkemauan keras untuk berusaha secara maksimal memenuhi kebutuhan hidupnya tanpa merasa takut dengan resiko yang akan terjadi. Minat berwirausaha meliputi: kesediaan untuk bekerja keras, tekun untuk mencapai usahanya, kesediaaan untuk menanggung macam-macam resiko berkaitan dengan tindakan usaha yang dilakukannya, kesediaan untuk hidup hemat dan kesediaan untuk belajar dari kegagalan yang dialami. Jadi yang dimaksud minat berwirausaha adalah keinginan ketertarikan serta kesediaan untuk bekerja keras untuk berdikari dalam memenuhi kebutuhan hidupnya

\section{Pendidikan Kewirausahaan}

Kewirausahaan sudah merambah ke dalam dunia pendidikan, diintegrasikan dengan kurikulum di sekolah maupun perguruan tinggi. Istilah kewirausahaan pun semakin populer dikalangan masyarakat. Pendidikan kewirausahaan merupakan nsalah satu bentuk aplikasi kepedulian dunia pendidikan terhadap kemajuan bangsanya. Di dalam pendidikan kewirausahaan diperlihatkan ndiantaranya adalah nilai dan bentuk kerja unruk mencapai kesuksesan.

Menurut Kadarsih (2013:99), pendidikan kewirausahaan adalah pertolongan untuk membelajarkan manusia Indonesia sehingga mereka memiliki kekuatan pribadi yang dinamis dan kreatif sesuai dengan kepribadian bangsa Indonesia yang berdasarkan pancasila. Pengertian tersebut senada dengan pendapat Wibowo (dalam Wahyono, 2013), pendidikan kewirausaahn merupakan upaya menginternalisasikan jiwa dan mental kewirausahaan baik melalui institusi pendidikan maupun institusi lain seperti lembaga pelatihan, training dan sebagainya.

Berdasarkan uraian di atas dapat disimpulkan bahwa pendidikan kewirausahaan merupakan usaha sadar yang dilakukan oleh lembaga pendidikan untuk menanamkan pengetahuan, nilai-nilai, jiwa dan sikap kewirausahaan kepada peserta didik.

Pendidikan kewirausahaan bertujuan untuk membentuk manusia secara utuh, memiliki karakter, pemahaman dan keterampilan sebagai wirausaha. Pada dasarnya, pendidikan kewirausahaan dapat diimplementasikan secara terpadu dengan kegiatankegiatan pendidikan di sekolah atau di lembaga pendidikan yang lebih tinggi. Pendidikan kewirausahaan diterapkan ke dalam kurikulum dengan cara mengidentifikasi jenis-jenis kegiatan di kampus yang dapat merealisasikan pendidikan kewirausahaan dan direalisasikan oleh mahasiswa dalam kehidupan sehari-hari (wordpress, 2011).

Menurut Kasmir (2011:32), Untuk menjadi wirausaha yang berhasil, persyaratan utama yang harus dimiliki adalah jiwa dan watak kewirausahaan. Jiwa dan watak tersebut dipengaruhi oleh keterampilan, kemampuan atau kompetensi. Kompetensi itu sendiri ditentukan oleh pengetahuan dan pengalaman usaha. Seorang wirausaha harus mampu berkreasi dan berinovasi. Kemampuan kreatif dan inovatif tersebut secara riil tercermin dalam kemampuan dan kemauan untuk memulai usaha (start up), kemampuan untuk mengerjakan sesutu yang baru (creative), kemauan dan kemampuan untuk mencari peluang (opportunity) dan kemampuan dan keberanian menanggung resiko (risk bearing). Kemamampuan yang dimiki oleh seoarang wirausaha tersebut diperoleh melalui 
pendidikan kewirausahaan yang sekarang ini sedang digencarkan oleh pemerintah melalui dunia pendidikan.

\section{METODE PENELITIAN \\ Populasi dan Sampel}

Populasi dalam penelitian ini adalah semua mahasiswa Universitas Samawa yang telah menempuh pendidikan kewirausahaan tahun Akademik 2013/2014 yang berjumlah 304 orang dan jumlah sampel sebesar 120 mahasiswa .

\section{Peubah yang Diamati / diukur}

Sesuai dengan judul penelitian ini, pengaruh pendidikan kewirausahaan terhadap minat berwirausaha mahasiswa Universitas Samawa Sumbawa Besar, maka Peubah yang diukur adalah minat berwirausaha mahasiswa.

\section{Teknik Pengumpulan Data}

Teknik pengumpulan data yang digunakan dalam penelitian ini adalah:

a. Angket

Teknik angket disebut pula sebagai teknik kuesioner, yaitu pengumpulan data dengan cara menyebarkan angket atau memberi seperangkat pertanyaan tertulis kepada responden untuk dijawab. Dalam hal ini angket diberikan kepada 120 mahasiswa yang menjadi responden.

\section{b. Dokumentasi}

Merupakan teknik pengumpulan data yang diperoleh dari dokumen-dokumen yang ada atau catatan-catatan yang tersimpan, baik itu berupa buku, surat kabar dan sebagainya. Dalam penelitian ini dokumen yang dibutuhkan adalah data tentang jumlah mahasiswa yang sudah menempuh pendidikan kewirausahaan.

\section{Identifikasi Variabel}

Variabel-variabel yang diteliti dalam penelitian ini adalah:

1. Kemampuan untuk memulai usaha $\left(\mathrm{X}_{1}\right)$

2. Kemampuan untuk mengerjakan sesuatu yang baru $\left(\mathrm{X}_{2}\right)$

3. Kemampuan untuk mencari peluang $\left(\mathrm{X}_{3}\right)$

4. Keberanian menanggung resiko $\left(\mathrm{X}_{4}\right)$

5. Minat berwirausaha (Y)

\section{Klasifikasi Variabel}

Variabel yang diidentifikasikan di atas, diklasifikasikan sebagai berikut:

1) Variabel Independen adalah variabel yang tidak dipengaruhi oleh variabel lain, yang dalam penelitian ini adalah Kemampuan Untuk Memulai usaha, Kemampuan Untuk Mengerjakan Sesuatu Yang Baru,Kemampuan Untuk Mencari Peluang, dan Keberanian Menanggung Resiko.

2) Variabel Dependen adalah variabel yang dipengruhi oleh variabel lainnya, dalam penelitian ini adalah Minat Berwirausaha.

\section{Uji Instrumen Penelitian}

\section{a. Uji Validitas}

Uji validitas yang digunakan dalam penelitian ini adalah uji validitas item, yaitu pengujian validitas terhadap kualitas item-itemnya. Dasar kerjanya dengan komputasi kolerasi antara setiap item dengan skor total tes sebagai kriteria validitasnya.

Menghitung nilai $\mathrm{r}$ (koefisien korelasi) dengan menggunakan teknik korelasi Product Moment Pearson dengan formulasi koefisien sebagai berikut (Sugiyono, 2009:177) :

$$
r=\frac{n\left(\sum \mathrm{XY}\right)-\left(\sum \mathrm{X} \sum \mathrm{Y}\right)}{\sqrt{\left[n \sum \mathrm{X}^{2}-\left(\sum \mathrm{X}\right)^{2} \llbracket n \sum \mathrm{Y}^{2}-\left(\sum \mathrm{Y}\right)^{2}\right]}}
$$




\section{b. Uji Reliabilitas}

Reliabilitas menunjukkan konsistensi suatu alat ukur di dalam mengukur gejala yang

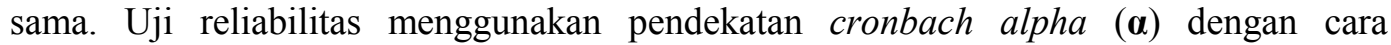
memasukkan butir-butir hasil jawaban responden untuk masing-masing variabel ke dalam perhitungan reliability analysis program SPSS. Suatu konstruk atau variabel dikatakan reliabel apabila memberikan nilai cronbach alpha $(\boldsymbol{\alpha})>0,6$ (Priyatno, 2012).

Adapun rumus Alpha Croanbach adalah sebagai berikut :

$$
r_{11}=\left[\frac{k}{k-1}\right]\left[1-\frac{\sum \sigma_{b}{ }^{2}}{\sigma_{r}{ }^{2}}\right]
$$

\section{Uji Asumsi Klasik}

\section{a. Uji Normalitas}

Uji normalitas pada regresi digunakan untuk menguji apakah nilai residual yang dihasilkan dari regresi terdistribusi secara normal atau tidak. Beberapa metode uji normalitas yaitu dengan melihat penyebaran data pada sumber diagonal pada garfik normal P-P Plot of regression standardized Residual atau dengan uji One Sample KolmogorovSmirnov (Priyatno, 2012).

\section{b. Multikolinieritas}

Untuk mendeteksi ada tidaknya multikolineritas dapat dilakukan dengan cara melihat nilai variance inflation factor (VIF) pada masing-masing variabel bebas. Nilai VIF lebih kecil dari 10 maka dalam model regresi tidak terdapat gejala multikolinearitas

\section{c. Heteroskedastisitas}

Uji Heteroskedastisitas digunakan untuk menguji apakah dalam sebuah model regresi terjadi ketidaksamaan varian dari residual pada suatu pengamatan yang lain. Jika terdapat perbedaan varians, maka dijumpai gejala Heteroskedastisitas.

\section{Uji Hipotesis}

\section{a. Analisa Regresi Berganda}

Analisis data menggunakan regresi berganda untuk mengetahui pengaruh variabel independen terhadap variabel dependen. Formulasi yang dihasilkan dalam bentuk sebagai berikut:

$$
\mathbf{Y}=\mathbf{a}+\mathbf{b}_{1} \mathbf{X}_{1}+\mathbf{b}_{2} \mathbf{X}_{2}+\mathbf{b}_{3} \mathbf{X}_{3}+\mathbf{b}_{4} \mathbf{X}_{4}+\mathbf{e}
$$

\section{b. Uji t Hitung}

Metode pengujian ini digunakan untuk mengetahui derajat keyakinan antara variabel yang diteliti secara parsial dengan persamaan sebagai berikut:

$$
t_{\text {hitung }}=\frac{b_{1}}{s e\left(b_{1}\right)}
$$

HASIL DAN PEMBAHASAN

Karakteristik Responden Berdasarkan Jenis Kelamin bawah ini:

Karakteristik responden berdasarkan Jenis Kelamin dapat dilihat pada tabel 1 di

Tabel 1 Kondisi Responden Berdasarkan Jenis Kelamin

\begin{tabular}{|l|l|l|l|}
\hline No & Jenis Kelamin & $\begin{array}{l}\text { Jumlah } \\
\text { (orang) }\end{array}$ & $\begin{array}{l}\text { Prosentase } \\
(\%)\end{array}$ \\
\hline 1 & Laki-laki & 52 & 43,3 \\
\hline 2 & Perempuan & 68 & 56,7 \\
\hline & Jumlah & 120 & 100 \\
\hline
\end{tabular}


Apabila dilihat dari kondisi responden berdasarkan jenis kelamin, maka diketahui sebanyak 52 orang $(43,3 \%)$ responden berjenis kelamin laki-laki, sedangkan 68 orang $(56,7 \%)$ berjenis kelamin perempuan. Hal ini menunjukkan bahwa sebagian besar responden berjenis kelamin perempuan.

\section{Uji Asumsi Klasik}

\section{a. Uji Normalitas}

Uji Normalitas digunakan untuk menguji apakah nilai residual yang dihasilkan dari regresi terdistribusi normal atau tidak. Pada gambar 1 diketahui bahwa titik-titik menyebar sekitar garis dan mengikuti garis diagonal maka nilai residual tersebut telah normal.

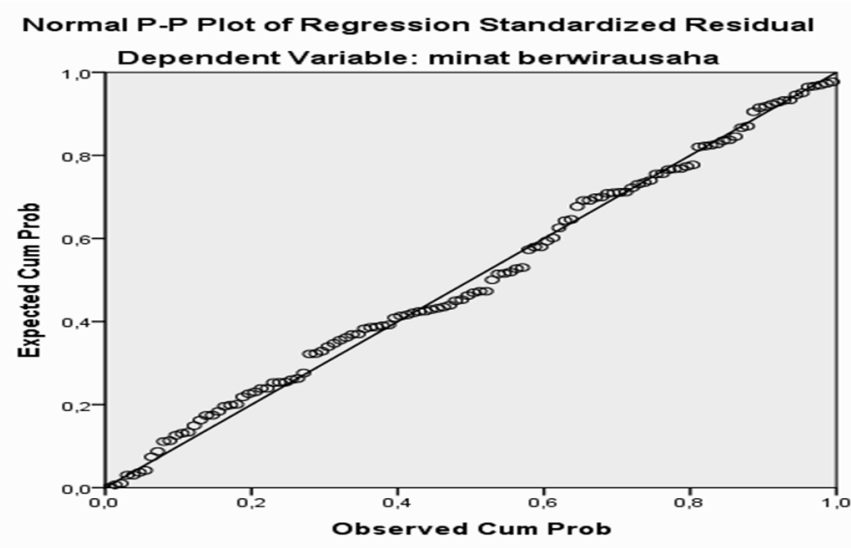

Gambar 1 Uji Normalitas

\section{b. Uji Multikolinearitas}

Multikolinearitas adalah keadaan dimana pada model rekresi tidak ditemukan adanya korelasi yang sempurna atau mendekati sempurna antarvariabel independen (korelasi 1 atau mendekati 1). Untuk mendeteksi ada tidaknya Multikolinearitas dilakukan dengan melihat nilai toleransi dan inflation factor (VIF) pada model regresi. Apabila nilai VIF kurang dari 10 dan angka toleransi lebih dari 0,1, maka tidak terjadi masalah multikolinearitas.

\section{Coefficients $^{\mathrm{a}}$}

Tabel 2 Hasil Uji Multikolinearitas

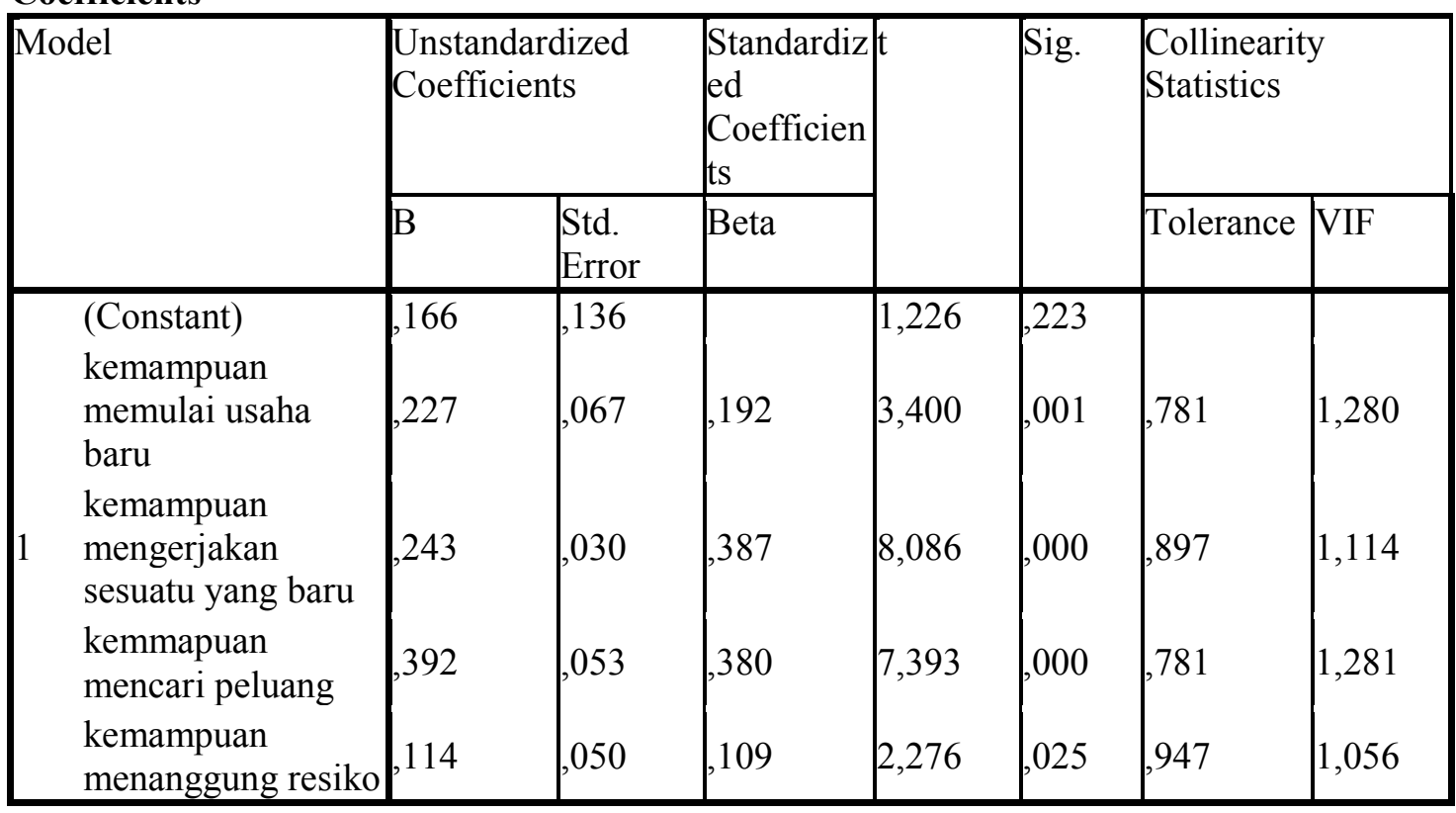

a. Dependent Variable: minat berwirausaha 
Dari tabel di atas dapat diketahui bahwa nilai toleransi ketiga variabel lebih dari 0,10 dan niali VIF kurang dari 10. Maka dapat disimpulkan bahwa tidak terjadi masalah multikolinearitas.

\section{c. Uji Heteroskedastisitas}

Heteroskedastisitas adalah keadaan di mana dalam model regresi terjadi ketidaksamaan varian dari residual pada satu pengamatan ke pengamatan lainnya. Salah satu cara uji heteroskedastisitas yaitu dengan melihat pola titik-titik pada scatterplots regresi. Berdasarkan gambar 2 dapat diketahui bahwa titik-titik tidak membentuk pola yang jelas. Titik-titik menyebar di atas dan di bawah angka 0 pada sumbu Y. Jadi dapat disimpulkan tidak terjadi masalah Heteroskedastisitas pada model regresi.

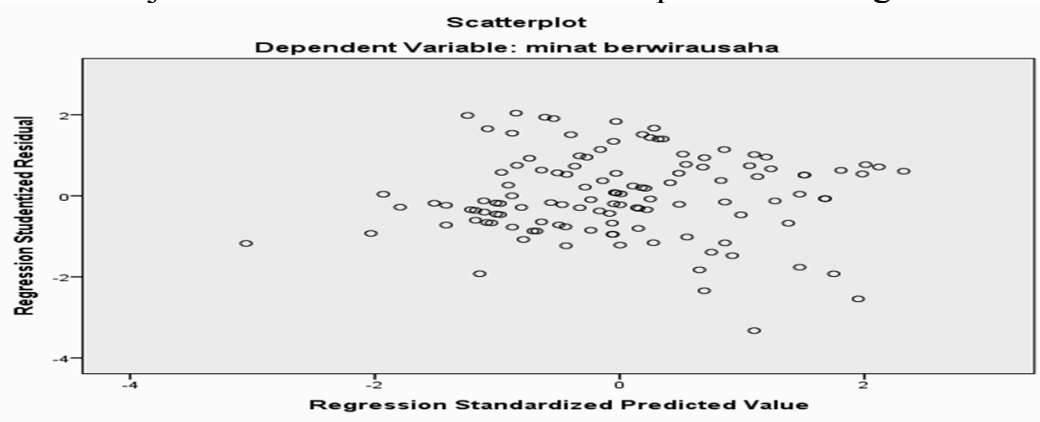

Gambar 2 Uji Heteroskedastisitas

\section{d. Uji Autokorelasi}

Autokorelasi adalah keadaan dimana pada model regresi ada korelasi antara residual pada peroide $t$ dengan residual pada periode sebelumnya ( $t-1)$. Model regresi yang baik adalah yang tidak terdapat masalah aotokorelasi. Metode pengujian menggunakan DurbinWatson (D-W test). Pada tabel 5.5 memperlihatkan angka D-W berada diantara -2sampai dengan +2 , maka tidak terdapat masalah autokorelasi dalam model regresi.

Tabel 3 Hasil Uji Autokorelasi

\begin{tabular}{|l|l|l|l|l|}
\hline Model & R & R Square & $\begin{array}{l}\text { Std. Error of the } \\
\text { Estimate }\end{array}$ & Durbin-Watson \\
\hline 1 &, $942^{\mathrm{a}}$ &, 887 &, 13582 & 1,901 \\
\hline
\end{tabular}

\section{Analisis Regresi Linier Berganda}

Analisis Regresi Linier Berganda adalah analisis untuk mengukur besarnya pengaruh variabel kemampuan memulai usaha, kemampuan mengerjakan sesuatu yang baru, kemampuan mencari peluang dan keberanian menanggung resiko terhadap minat berwirausaha

Tabel 4 Hasil Analisis Regresi Berganda dan Determinasi

\begin{tabular}{|l|l|l|l|l|}
\hline Model & R & R Square & $\begin{array}{l}\text { Adjusted R } \\
\text { Square }\end{array}$ & $\begin{array}{l}\text { Std. Error of the } \\
\text { Estimate }\end{array}$ \\
\hline 1 &, $942^{\mathrm{a}}$ &, 887 &, 883 &, 13582 \\
\hline
\end{tabular}

Berdasarkan tabel 4 di atas bahwa hubungan antara variabel kemampuan memulai usaha baru, kemampuan mengerjakan sesuatu yang baru, kemampuan mencari peluang dan keberanian menanggung resiko dengan minat berwirausaha adalah kuat dan positif. Hal tersebut dibuktikan dengan $\mathrm{R}$ sebesar 0,942. Kemudian koefisien determinasi berganda 
atau $\mathrm{R}^{2}$ sebesar 0,887 , memberikan makna bahwa keempat variabel independen secara bersama-sama atau simultan berpengaruh besar terhadap minat berwirausaha mahasiswa Universitas Samawa Sumbawa Besar. Dengan kata lain keempat variabel indipenden tersebut berpengaruh sebesar $88,70 \%$ terhadap minat berwirausaha mahasiswa, sedangkan sisanya $11,30 \%$ dipengaruhi oleh variabel lain yang tidak termasuk dalam penelitian ini.

\section{Analisis Uji F}

Tabel 5 ANOVA Untuk Uji F

\begin{tabular}{|c|c|c|c|c|c|}
\hline Model & Sum of Squares & df & Mean Square & $F$ & Sig. \\
\hline Regression & 16,657 & 4 & 4,164 & 225,749 &, $000^{\mathrm{b}}$ \\
\hline Residual & 2,121 & 115 &, 018 & & \\
\hline Total & 18,778 & 119 & & & \\
\hline
\end{tabular}

Berdasarkan tabel di atas, diketahui $\mathrm{F}$ hitung sebesar 225,749 dengan tingkat signifikansi 0,000 . Sedangkan nilai $\mathrm{F}$ tabel ditentukan berdasarkan tabel $\mathrm{F}$ pada tingkat signifikansi $5 \%$ dengan df $1=4$ dan df $2=115$. Karena nilai $F$ hitung $>F$ tabel $(225,749>$ 2,451), maka Ho ditolak dan Ha diterima, artinya kemampuan memulai usaha baru (X1), kemampuan mengerjakan sesuatu yang baru (X2), kemampuan mencari peluang (X3) dan keberanian menanggung resiko (X4) secara simultan berpengaruh signifikan terhadap minat berwirausaha mahasiswa (Y). Berdasarkan hasil perhitungan tersebut, maka masingmasing koefisien beta yaitu, kemampuan memulai usaha baru, kemampuan mengerjakan sesuatu yang baru, kemampuan mencari peluang dan keberanian menanggung resiko akan dapat meningkatkan minat berwirausaha

\section{Pengaruh Kemampuan Memulai Usaha Baru (X1) terhadap Minat Berwirausaha (Y)}

Kemampuan memulai usaha baru mempunyai pengaruh positif terhadap minat berwirausaha Mahasiswa (Y). Hal ini mengindikasikan bahwa peningkatan kemampuan memulai usaha baru memberikan pengaruh peningkatan terhadap minat berwirausaha. Sebaliknya bila terjadi penurunan kemampuan memulai usaha baru akan menyebabkan penurunan pada minat berwirausaha. Maknanya adalah dengan meningkatnya kecakapan, kemampuan mengorganisir suatu pekerjaan, menemukan gagasan, memelihara hubungan baik dengan relasi serta kemampuan komunikasi dan negosiasi yang baik dengan mitra, maka hal ini jelas akan mendorong peningkatan minat berwirausaha mahasiswa.

\section{Pengaruh Kemampuan Mengerjakan Sesuatu Yang Baru (X2) terhadap Minat Berwirausaha (Y)}

Kemampuan mengerjakan sesuatu yang baru berpengaruh positif terhadap minat berwirausaha (Y). Hal ini mengindikasikan bahwa peningkatan kemampuan mengerjakan sesuatu yang baru memberikan pengaruh peningkatan terhadap minat berwirausaha. Sebaliknya bila terjadi penurunan Kemampuan mengerjakan sesuatu yang baru akan menyebabkan penurunan pada minat berwirausaha. Maknanya adalah dengan meningkatnya kemampuan tentang cara memproduksi barang/jasa, kemampuan dalam menemukan pasar dan pelanggan serta menentukan harga yang tepat, dan dengan meningkatnya kemampuan memperoleh sumber-sumber dana dan cara menggunakannya maka hal ini akan mendorong peningkatan minat berwirausaha mahasiswa.

\section{Pengaruh Kemamapuan Mencari Peluang (X3) terhadap Minat Berwirausaha (Y)}

Kemamapuan mencari peluang berpengaruh positif terhadap minat berwirausaha. Hal ini terlihat pada koefisien regresi yang bertanda positif yang mengindikasikan bahwa peningkatan kemamapuan mencari peluang memberikan pengaruh peningkatan terhadap minat berwirausaha. Sebaliknya bila terjadi penurunan Kemamapuan mencari peluang akan menyebabkan penurunan pada minat berwirausaha. Maknanya adalah dengan 
meningkatnya semangat dan kemampuan dalam mencari dan menangkap peluang usaha, maka hal ini jelas akan mendorong peningkatan terhadap minat berwirausaha

\section{Pengaruh Keberanian menanggung resiko (X4) terhadap minat berwirausaha (Y)}

Keberanian menanggung resiko berpengaruh positif terhadap minat berwirausaha. $\mathrm{Hal}$ ini terlihat pada koefisien regresi yang bertanda positif yang mengindikasikan bahwa peningkatan keberanian menanggung resiko memberikan pengaruh peningkatan terhadap minat berwirausaha. Sebaliknya bila terjadi penurunan Keberanian menanggung resiko akan menyebabkan penurunan pada minat berwirausaha. Maknanya adalah dengan meningkatnya keberanian dalam menghadapi dunia usaha yang tidak menentu, keberanian dan kemampuan mengendalikan kegagalan, dan keberanian untuk bangkit kembali dari kegagalan, hal ini jelas akan mendorong peningkatan terhadap minat berwirausaha.

Pengaruh Kemampuan Memulai Usaha Baru (X1), Kemampuan Mengerjakan Sesuatu Yang Baru (X2), Kemamapuan Mencari Peluang (X3) dan Keberanian menanggung resiko $(\mathrm{X} 4)$ terhadap minat berwirausaha $(\mathrm{Y})$

Dari hasil analisis regresi diketahui bahwa variabel Memulai Usaha Baru, Kemampuan Mengerjakan Sesuatu Yang Baru, Kemamapuan Mencari Peluang dan Keberanian menanggung resiko secara bersama-sama berpengaruh secara positif dan signifikan terhadap minat berwirausaha mahasiswa. Hal ini dibuktikan dengan hasil uji $\mathrm{F}$, dimana $\mathrm{F}$ hitung $>\mathrm{F}$ tabel $(77,471>2,794)$. Hal ini menandakan bahwa guru PJOK memberikan respon yang positif terhadap kemampuan, motivasi, dan dukungan organisasi, dalam arti mereka mengedepankan aspek kemampuan, motivasi serta mampu memanfaatkan

\section{SIMPULAN}

Berdasarkan hasil analisis data maka dapat disimpulkan bahwa pendidikan kewirausahaan berpengaruh terhapa minat berwirausaha mahasiswa Universitas Samawa Sumbawa Besar.

\section{DAFTAR PUSTAKA}

Alma, Buchari, 2010, Kewirausahaan, Alfabeta, Bandung

Fuadi, Iski Fadli. 2009. Hubungan Minat Berwirausaha Dengan Prestasi Praktik Kerja Industri Siswa kelas XII teknik otomatif SMK Negeri 1 Adiwerna Kabupaten Tegal. Jurnal PTM. Vol.9. Desember 2009. Hal, 92-98

Kadarsih, Retno, 2011,. Faktor-faktor Yang Mempengaruhi Minat Berwirausaha Mahasiswa Program Studi Pendidikan Ekonomi FKIP UNS, Jupe UNS, Vol, 2 No, 1 tahun 2013, Hal, 95-106

Kasmir, 2011, Kewirausahaan, Rajagrafindo Persada, Jakarta

Lambing, P. \& Kuehl. 2007, Entrepreneurship. 4th edition, Prentice Hall, Upper Saddle River.

Lestari, Retno B., Trisnadi, W, 2012, Pengaruh Pendidikan Kewirusahaan Terhadap Minat Berwirausaha Mahasiswa Di STIE MDP, STIKA MDP, DAN STIE MUSI, Jurnal Ilmiah STIE MDP, Vol, 1 No, 2, Maret 2012, Hal, 112-119

Mahesa, A dan Rahardja, E, 2012, Analisis faktor-faktor motivasi yang mempengaruhi minat berwirausaha. Diponegoro journal of managament. Vo, 1, No. 1, Hal, 130-137

Martono, 2011, Metode Penelitian Kuantitatif, Analisis Isi Dan Analisis Data Sekunder, Cetakan ke 2, PT. Raja Grafindo Persad, Jakarta

Mulyati, 2005, Psikologi Belajar, Andi publisher, Yogyakarta 
Priyanto, D. (2008), Mandiri Belajar SPSS Untuk analisis Data \& Uji Statistik Bagi Mahasiswa dan Umum, Mediakom, Yogyakarta

Putra, R Aditya, 2012, Faktor-faktor Penentu Minat Mahasiswa Manajemen Fakultas Ekonomi Universita Negeri Padang. Jurnal manajemen, Vol, 01, N0, 01 September 2012, hal, 1-12.

Purwinarti, Titik, (2006), Faktor-faktor Pendorong Minat berwirausaha (Studi Lapangan Terhadap Politeknik UNJ), Jurnal penelitian Ekonomi dan Bisnin, Vol, 5 No. 1, Maret 2006, Hal. 39-46

Pusat Kurikulum Balitbang Kemendiknas, 2010, Pengembangan Pendidikan Kewirausahaan; Bahan Pelatihan Penguatan Metodelogi Pembelajaran Berdasarkan Nilai-Nilai Budaya Untuk Membentk Daya Saing Dan Karakter Bangsa, Jakarta 